\title{
A thiol-mediated active membrane transport of selenium by erythroid anion exchanger 1 protein
}

\author{
Masafumi Hongoh, Mamoru Haratake,* Takeshi Fuchigami and Morio Nakayama*
}

Graduate School of Biomedical Sciences, Nagasaki University, 1-14 Bunkyo-machi, Nagasaki 852-8521, Japan. E-mail: haratake@nagasaki-u.ac.jp (M. Haratake); morio@nagasaki-u.ac.jp (M.Nakayama)

In this paper, we describe a thiol-mediated and energy-dependent membrane transport of selenium by erythroid anion exchanger 1 (AE1, also known as band 3 protein). The AE1 is the most abundant integral protein of red cell membranes and plays a critical role in the carbon dioxide transport system in which carbon dioxide is carried as bicarbonate in the plasma. This protein mediates the membrane transport of selenium, an essential antioxidant micronutrient, from red cells to the plasma in a manner that is distinct from the already known anion exchange mechanism. In this pathway, selenium bound to the cysteine 93 of the hemoglobin $\beta$ chain (Hb-Cys $\beta 93$ ) is transported by the relay mechanism to the Cys 317 of the amino-terminal cytoplasmic domain of the AE1 on the basis of the intrinsic interaction between the two proteins and is subsequently exported to the plasma via the Cys 843 of the membrane-spanning domain. The selenium export did not occur in plain isotonic buffer solutions and required thiols, such as albumin, in the outer medium. Such a membrane transport mechanism would also participate in the export pathways of the nitric oxide vasodilator activity and other thiol-reactive substances bound to the Hb-Cys $\beta 93$ from red cells to the plasma and/or peripherals. 


\section{Introduction}

Selenium belongs to chalcogens that shares similar chemical properties especially with sulfur and, to a lesser extent, with tellurium. This element is an essential micronutrient for humans and other higher animal species. ${ }^{1}$ Selenocysteine (SeCys), the 21st naturally occurring amino acid encoded by the UGA codon, is the form of selenium present in enzymes and proteins. In humans, 25 SeCys-containing proteins (selenoproteins) are identified on the basis of their selenoproteome analysis. ${ }^{2}$ The best-known selenoproteins are the glutathione peroxidases (GPxs) that can catalyze the reduction of certain peroxide species $(\mathrm{R}-\mathrm{OOH})$ to the alcohols $(\mathrm{R}-\mathrm{OH})$ at their active center SeCys residue. ${ }^{1,3}$

Nutritional selenium is thought to be obtained from a variety of selenium compounds in the diet, mostly in organic forms, such as SeCys and selenomethionine (SeMet). During the systemic delivery of selenium, selenoprotein $\mathrm{P}$ that is present in the plasma is thought to be the selenium supply protein for the biosynthesis of the other selenoproteins including GPxs. ${ }^{4,5}$ Recent evidence in selenoprotein P (SelP) knockout mice has shown that the distribution of selenium from the liver to testis and brain is mediated by Sel $\mathrm{P}^{6,7}$ It is also found that in the absence of SelP, selenium from selenious acid $\left(\mathrm{SA}, \mathrm{H}_{2} \mathrm{SeO}_{3}\right)$ in the diet can be distributed to the peripherals by a yet unknown mechanism. ${ }^{8}$ So far, little is known about the membrane transport of selenium from selenium source compounds, including SA. Inorganic SA is rare as a chemical form of the food source compounds, but highly bioavailable SA is most frequently used as a source compound for the treatment of a selenium deficiency. ${ }^{9}$ Selenium-enriched yeast (a common form of selenium supplement) is found to contain significant amounts of SA. ${ }^{10,11} \mathrm{SA}$ is also used to supplement infant formula and other 
products. ${ }^{12,13}$ Thus, a better understanding of the systemic delivery mechanisms of selenium from SA is of significance from the viewpoints of medical treatments and toxicology. In the bloodstream, SA is immediately taken up from the plasma into the red cell through the band 3 protein (anion exchanger $1, \mathrm{AE} 1)^{14}$ and then returned to the plasma after reductive metabolism in the red cells. ${ }^{15-17}$

AE1 is the most abundant integral protein of the red cell membrane, constituting $\sim 25-30 \%$ of the total protein mass in the purified membrane, with approximately $10^{6}$ copies present per cell. ${ }^{18}$ The AE1 is a 911-amino acid-long glycoprotein (molecular mass 95 $\mathrm{kDa}$ ) involving structurally distinct domains, that is, a large amino-terminal cytoplasmic domain (N-CPD, Met1-Pro403), a membrane-spanning domain (MSD, Gln404-Glu882) containing a single $N$-linked glycosylation site, Asn642, on its extracellular surface and a short carboxyl-terminal cytoplasmic domain (C-CPD, Leu883-Val911). ${ }^{19-21}$ In the native membrane, the AE1 is known to be present at $60 \%$ in dimeric and $40 \%$ in tetrameric forms and forms a macrocomplex with other integral proteins and cytoskeletal proteins. ${ }^{22}$

The AE1 plays a critical role in the carbon dioxide transport system in which carbon dioxide is carried as bicarbonate in the blood plasma. Because the solubility of carbon dioxide in the blood plasma is rather low, the carbon dioxide molecule that diffuses into the red cell is converted into the bicarbonate anion by cytosolic carbonic anhydrase. The bicarbonate anion is then transported out of the red cell by the AE1 during the exchange with a chloride anion $\left(\mathrm{Cl}^{-} / \mathrm{HCO}_{3}^{-}\right.$anion exchange). The MSD mediates the anion exchange, while the C-CPD contains acidic motifs that constitute a core binding site for cytoplasmic carbonic anhydrase $\mathrm{II}^{9}$ and is required for the $\mathrm{Cl}^{-} / \mathrm{HCO}_{3}^{-}$exchange process. ${ }^{23,24}$ The extreme sequence of the N-CPD binds multiple glycolytic enzymes ${ }^{25}$ and hemoglobin $(\mathrm{Hb}){ }^{26}$ Other 
parts of this domain also provide binding sites for the cytoskeletal proteins ankryin ${ }^{27}$ protein 4.1 $1^{28}$ and protein 4.2. ${ }^{29} \quad$ A major function of the N-CPD is thought to anchor the membrane to the underlying cytoskeleton, which is important for organizing the structure of the membrane and its attachment to the cytoskeleton. The AE1 protein also constitutes the major glucose transporter of human erythrocytes and is probably a multifunctional transport protein responsible for the transport of glucose, anions, and water. ${ }^{30}$

The AE1 contains five cysteine residues: Cys201 and Cys317 in the N-CPD, Cys479 and Cys843 in the MSD, and Cys885 in the C-CPD. ${ }^{31}$ Casey et al. mutated each of these cysteines to serine to examine their role in the function of the AE1 and stated that the cysteine residues of the human AE1 are not required for the anion exchange and cytoskeletal binding roles of the protein, ${ }^{32}$ although the membrane domain can mediate anion transport even after the removal of the N-CPD. ${ }^{33,34}$ The N-CPD are known to possess an intrinsic binding affinity for the $\mathrm{Hb}$ and to undergo the formation of intermolecular disulfide bonds between the Cys201 and/or the Cys317 and the Cys $\beta 93$ of $\mathrm{Hb}$ under certain conditions. ${ }^{35}$ Recently, Stamler and his colleagues reported that an export function of nitric oxide (NO) vasodilator activity from red cells to the plasma and/or the peripherals is involved in the transport of NO bound to the Cys $\beta 93$ of $\mathrm{Hb}$ to thiols of the N-CPD (Hb-Cys $\beta 93-\mathrm{SNO}+\mathrm{N}-\mathrm{CPD}-\mathrm{Cys}-\mathrm{SH} \rightarrow$ Hb-Cys $\beta 93-\mathrm{SH}+\mathrm{N}-\mathrm{CPD}-\mathrm{Cys}-\mathrm{SNO}){ }^{36,37}$ Such NO transport could possibly be effected by the direct transfer of NO from one thiol to another without the generation of free NO via an intermediate R-S-N(O)-S-R species. ${ }^{38}$ However, molecular details of the subsequent NO membrane transport mediated by AE1 have not yet been verified.

After the immediate uptake by the anion exchange function of the AE1 into red cells, ${ }^{14}$ SA is reductively metabolized by glutathione to transform selenotrisulfide (R-SSeS-R), and is 
then bound to the Cys $\beta 93$ of $\mathrm{Hb}$ by thiol exchange (Hb-Cys $\beta 93-\mathrm{SSeS}-\mathrm{R})$. Selenium bound to the $\mathrm{Hb}$ is subsequently transferred to thiols of the N-CPD in a similar manner to NO. The selenium export to the plasma across the membranes occurs in an oxygen-linked fashion; it is enhanced by increasing the proportion of the deoxygenated $\mathrm{Hb}$ with a higher binding affinity for the N-CPD than the oxygenated $\mathrm{Hb}$, similar to the NO export fashion. ${ }^{39}$ Chemical modification of thiols in both the N-CPD and the MSD of the AE1 results in complete inhibition of the selenium export from red cells. ${ }^{40}$ In the present study, we investigated the selenium transport mechanism across red cell membranes from $\mathrm{Hb}$ to the plasma and proposed a possible mechanism for a thiol-mediated membrane transport of selenium by the erythroid AE1 protein.

\section{Experimental}

\section{Determination of membrane protein and selenium concentrations}

The protein concentrations were colorimetrically determined by a bicinchoninic acid protein assay using bovine serum albumin as the reference. 2,2'-Bicinchoninic acid and $\mathrm{Cu}$ (II) sulfate were added to the red cell membrane samples dissolved in a $5 \mathrm{mM}$ sodium phosphate solution ( $\mathrm{pH} 8,5 \mathrm{P} 8)$ containing $1 \%$ sodium dodecyl sulfate (SDS). The mixtures were then allowed to react at $60{ }^{\circ} \mathrm{C}$ for $30 \mathrm{~min}$. The produced color was monitored at $562 \mathrm{~nm}$.

The selenium concentrations in the specimens were fluorometrically determined using 2,3-diaminonaphthalene (DAN, Tokyo Chemical Industry Co., Ltd.) after acid digestion with a 1 : 5 mixture by volume of perchloric acid and nitric acid. ${ }^{41}$ The selenium standard solution [1000 ppm as selenium (IV) dioxide in $0.5 \mathrm{M}$ nitric acid] for the fluorometry was 
obtained from Kanto Chemical Co., Inc.

\section{Selenium export experiments from red cells}

Fresh human venous blood was collected in a heparinized VENOJECT II tube (TERUMO). Each sample was centrifuged at $1400 \mathrm{~g}$ for $10 \mathrm{~min}$ at room temperature, and the plasma, buffy coat and upper $10 \%$ of the red cell layers were removed by aspiration. The precipitated red cells were washed three times with $66 \mathrm{mM}$ phosphate buffer [285 milliosmols (isotonic), $\mathrm{pH}$ 7.4]. The purified red cells were incubated with selenious acid (SA, $8 \mu \mathrm{M}$, Kanto Chemical Co., Inc.) in the isotonic phosphate buffer (pH 7.4) and washed thoroughly with the same buffer. The SA-treated red cell precipitate was combined with an equal volume of human blood plasma, and the mixture was incubated in a water bath with shaking at $60 \mathrm{~min}^{-1}$. Aliquots were withdrawn from the mixture at appropriate time intervals. After centrifugation at $1400 \mathrm{~g}$ for $10 \mathrm{~min}$ at $4{ }^{\circ} \mathrm{C}$ to separate the red cells from the plasma, the selenium contents in the red cells and the plasma were determined by the DAN method subsequent to acid digestion. The selenium content in the red cell precipitates before mixing

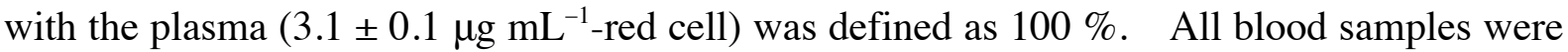
obtained from male healthy individuals according to the guidelines of the Ethics Committee of Nagasaki University.

\section{Isolation of red cell ghost membranes}

Unsealed red cell membranes were prepared according to the method of Steck and Kant. ${ }^{42}$ Isolated red cells were osmotically hemolyzed by the addition of cold 5P8. The hemolysate 
was centrifuged at $20,000 \mathrm{~g}$ and $4{ }^{\circ} \mathrm{C}$ for $20 \mathrm{~min}$ and then the supernatant was removed by aspiration. To remove hemoglobin bound to the membranes, the red pellets were washed thoroughly with 5P8 till the red-colored pellets become white.

\section{Sodium dodecyl sulfate-polyacrylamide gel electrophoresis (SDS-PAGE) and immunoblotting analyses.}

The crude membrane protein was dissolved in a mixture of $1 \%$ SDS, $0.01 \mathrm{M}$ tris(hydroxymethyl)aminomethane- $\mathrm{HCl}(\mathrm{pH} 8)$ and $10 \%$ sucrose. The membrane protein samples $(20-40 \mu \mathrm{g})$ were electrophoresed on a $7.5 \%$ polyacrylamide disk gel with an electrophoresis buffer [0.1 \% SDS, $25 \mathrm{mM}$ tris(hydroxymethyl)aminomethane and $192 \mathrm{mM}$ glycine] using a pageRun AE-6531M (ATTO Corporation). The gel electrophoresis was carried out under a non-reducing condition. The molecular mass calibration was carried out using Precision Plus Protein standards that contain ten bands of 10-250 kDa (Bio-Rad Laboratories). The locations of the proteins in the gels were determined using $0.1 \%$ Coomassie blue in $30 \%$ methanol-acetic acid mixed solution). For the immunoblotting analysis, the membrane proteins on the gels were transferred onto a $\mathrm{P}$ membrane (polyvinyl difluoride membrane, ATTO Corporation). The membrane samples were blocked with $1 \%$ nonfat milk in $0.1 \%$ Tween-20 supplemented $25 \mathrm{mM}$ tris(hydroxymethyl)aminomethaneHCl-buffered saline. The mouse monoclonal anti-human AE1 antibody, that is directed against within $20 \mathrm{kDa}$ from the amino-terminal domain, (Alpha Diagnostic Int'l, Inc.) at a 1:3,000 dilution was then applied, followed by goat antimouse antibody-horseradish peroxidase conjugate (Alpha Diagnostic Int'l, Inc.) at a $1: 17,500$ dilution. An LAS-1000 luminescent image analyzer (Fujifilm Co.) was used to detect the AE1 immunoblot. 


\section{Fractionation of red cell membrane proteins}

Isolated red cell membranes were fractionated as previously described with slight modification. ${ }^{40}$ To remove N-CPD from the membranes, selenium-bound membranes were first digested with $20 \mu \mathrm{g} \mathrm{mL} \mathrm{m}^{-1} \alpha$-chymotrypsin ( $\alpha$-Chy, from bovine pancreas, 35-65 units $\mathrm{mg}^{-1}$, Nacalai Tesque, Inc.) in $5 \mathrm{P} 8$ at $37{ }^{\circ} \mathrm{C}$ for $10 \mathrm{~min}$ and centrifuged at $20,000 \mathrm{~g}$ and $4{ }^{\circ} \mathrm{C}$ for 20 min [fraction (i)]. The $\alpha$-Chy-treated membranes were subsequently incubated with $0.1 \mathrm{M} \mathrm{NaOH}$ for $30 \mathrm{~min}$ on ice to remove peripheral proteins and washed three times with a cold 5P8 [fraction (ii)]. To separate C-CPD from the membranes, the membranes were further digested with $25 \mu \mathrm{g} \mathrm{mL} \mathrm{m}^{-1}$ trypsin [Try, from porcine pancreas, 1,000-2,000 units $\mathrm{mg}^{-1}$, salt free, Nacalai Tesque, Inc.] in $5 \mathrm{P} 8$ for $1 \mathrm{~h}$ at $37^{\circ} \mathrm{C}$ [fraction (iii)].

\section{Matrix-assisted laser desorption ionization-time of flight mass spectrometry} (MALDI-TOF MS).

Isolated red cell membranes were digested with $20 \mu \mathrm{g} \mathrm{mL}-1$-Chy in $5 \mathrm{P} 8$ at $37{ }^{\circ} \mathrm{C}$ for $10 \mathrm{~min}$. After centrifuging at $20,000 \mathrm{~g}$, the supernatant was collected as the N-CPD-containing fraction for the mass spectrometric analysis. The MSD of AE1 was separated according to the method of Abe et al. ${ }^{43}$ Red cell membranes were first treated with $1 \mu \mathrm{g} \mathrm{mL}{ }^{-1}$ Try in 5 $\mathrm{mM} \mathrm{NaHCO} 3$ on ice for $30 \mathrm{~min}$ to remove N-CPD. The trypsinized membranes were subsequently treated with $0.1 \mathrm{M} \mathrm{NaOH}$ for $30 \mathrm{~min}$ on ice and $25 \mu \mathrm{g} \mathrm{mL} \mathrm{m}^{-1}$ Try in $5 \mathrm{P} 8$ for $1 \mathrm{~h}$ at $37^{\circ} \mathrm{C}$. The resulting membranes were delipidated by a mixture of chloroform and methanol, and the deposited protein was dissolved in a $1: 2$ mixture by volume of acetonitrile and iso-propanol for the analysis. 
Sample solutions were mixed with an equal volume of matrix solution [saturated sinapinic acid in $0.1 \%$ trifluoroacetic acid (TFA) and $34 \%$ acetonitrile for the N-CPD containing fraction, and in $0.1 \%$ TFA and $50 \%$ acetonitrile for the MSD-containing fraction], and an aliquot was applied on an AnchorChip ${ }^{\mathrm{TM}}$ target (Bruker Daltonics, Inc.) that was loaded with a sinapinic acid matrix thin layer. Mass spectra were acquired in linear positive ion mode using an Ultraflex MALDI TOF/TOF mass spectrometer (Bruker Daltonics, Inc.). Spectra were calibrated with Protein Calibration Standard I (Bruker Daltonics, Inc.). Cys-containing fragments were identified by theoretical mass calculation using the protein prospector program (http://prospector.ucsf.edu/prospector/mshome) and chemical modification of cysteine residues by NEM.

\section{Reaction of Pen-SSeS-Pen with red cell membranes}

L-Penicillamine selenotrisulfide (Pen-SSeS-Pen) was synthesized from Pen and selenious acid according to a previously described procedure ${ }^{44,45}$ : Elemental analysis (\%), calculated for $\mathrm{C}_{10} \mathrm{H}_{20} \mathrm{~N}_{2} \mathrm{O}_{4} \mathrm{~S}_{2} \mathrm{Se}$ : C 31.97, H 5.33, N 7.46, Se 21.04; found: C 31.13, H 5.86, N 7.24, Se 21.89. MALDI-TOF MS, calculated for $\mathrm{C}_{10} \mathrm{H}_{20} \mathrm{~N}_{2} \mathrm{O}_{4} \mathrm{~S}_{2}{ }^{80} \mathrm{Se} ; 376.24$, found: 376.83. $[\alpha]_{\mathrm{D}},+7.07$. $\lambda_{\max }$ in deionized water $266 \mathrm{~nm}\left(\varepsilon_{\mathrm{mM}}: 1.47\right)$. Isolated red cell membranes were incubated with 0.1 or $1 \mathrm{mM}$ Pen-SSeS-Pen in $5 \mathrm{P} 8$ at $37^{\circ} \mathrm{C}$ for $30 \mathrm{~min}$. Thiol contents of the red cell membranes and Pen-SSeS-Pen solution before and after the reaction were measured by the DTNB method. Selenium binding sites analysis and MALDI-TOF MS were performed as mentioned above. $N$-Ethylmaleimide (NEM) and iodoacetamide (IAA) used for thiol alkylation were from Nacalai Tesque, Inc. The isolated red cell membranes were treated with $1 \mathrm{mM}$ NEM and $1 \mathrm{mM}$ IAA at $37{ }^{\circ} \mathrm{C}$ for $10 \mathrm{~min}$. Thiol content in the specimens was 
spectrophotometrically determined using 5,5'-dithiobis (2-nitrobenzoic acid) (DTNB, Sigma Co., Ltd.). The red cell membranes were suspended in 5P8 containing $1 \%$ SDS and added to an equal volume of a $1 \mathrm{mM}$ DTNB solution. The absorbance at $450 \mathrm{~nm}$ was measured at $1 \mathrm{~h}$ after incubation.

\section{Selenium export experiments from the resealed membranes}

Resealed red cell membranes were prepared from $8 \mu \mathrm{M}$ SA-treated red cells according to the method of Steck and Kant. ${ }^{42}$ After hemolysis, unsealed membranes were suspended in 40 volumes of phosphate-buffered saline (PBS) and incubated for $40 \mathrm{~min}$ at $37{ }^{\circ} \mathrm{C}$ to induce resealing. The membranes were then pelleted by centrifugation and washed twice with PBS. The quality of the resealed membrane was estimated from the determination of NADH-cytochrome c oxidoreductase activity, which resides on the cytoplasmic surface of the membrane. Briefly, the membranes were suspended in PBS with or without saponin, and then $\beta$-NADH and cytochrome $\mathrm{c}$ were sequentially added. The reaction was monitored at $550 \mathrm{~nm}$ for $10 \mathrm{~min}$. The resealed membrane purity was calculated using the following equation $\left(\Delta A_{\text {saponin (-) }} / \Delta A_{\text {saponin (+) }}\right) \times 100(\%)$, where $\Delta A_{\text {saponin (-) }}$ and $\Delta A_{\text {saponin (+) }}$, respectively, are the changes in absorbance at $550 \mathrm{~nm}$ of sample solutions between 0 and 10 min after addition of the substrate in the absence and presence of saponin. The quality of the resealed membrane was estimated to be $91.7 \pm 1.0 \%$ throughout the selenium export experiments. The selenium-bound resealed membrane suspension (protein concentration $343.6 \pm 2.4 \mu \mathrm{g} \mathrm{mL}^{-1}$ ) was then incubated with an equal volume of the plasma at $37{ }^{\circ} \mathrm{C}$ in a water bath with shaking at 60 strokes $\mathrm{min}^{-1}$. Aliquots were withdrawn from the mixture at the indicated time intervals. After centrifugation at $20,000 \mathrm{~g}$ for $20 \mathrm{~min}$ at $4{ }^{\circ} \mathrm{C}$ to separate the membranes and 
the plasma, the selenium contents in the four fractions were determined.

\section{Statistical analysis}

All data were presented as the mean and standard error of the mean (SEM) $(n=6)$. Statistical analyses were performed using PRISM4 (GraphPad Software, Inc.). The multiple mean values were compared by a two-way analysis of variance with a Bonferroni posthoc test. Comparisons were considered statistically significant at $P<0.05$.

\section{Results}

\section{Selenium export from red cells to the plasma}

The selenium export from the SA-treated red cells to the plasma was examined under various conditions. When the SA-treated red cells were incubated in the plasma at $37{ }^{\circ} \mathrm{C}$ (the control conditions), the selenium content in the red cells gradually decreased over 60 min, meanwhile, that in the plasma increased in an inverse manner (Fig. 1 a). No selenium export from the SA-treated red cells occurred when using isotonic buffer solutions instead of the plasma at $37^{\circ} \mathrm{C}$. The selenium species that once appeared in the plasma did not return to the red cells. Such a selenium export process was not suppressed by treatment of the red cells with 4,4'-diisothiocyanato-2,2'-stilbene disulfonate (DIDS), a specific AE1 inhibitor, at a concentration at which its anion exchange function is almost completely blocked (Fig. $1 \mathrm{~b}){ }^{46}$ To the contrary, incubation of the SA-treated red cells at $4{ }^{\circ} \mathrm{C}$ blocked the selenium export to the plasma in which the AE1 is active in the anion exchange function (Fig. $1 \mathrm{c}$ ). The selenium export activity was also inhibited by the pre-incubation in the isotonic phosphate 
buffer ( $\mathrm{pH}$ 7.4) for $2 \mathrm{~h}$, which results in ATP-depletion in red cells (Fig. $1 \mathrm{~d}$ ) but was maintained by the addition of adenosine 5'-triphosphate (ATP) source materials (5 mM glucose, $10 \mathrm{mM}$ inosine and $2 \mathrm{mM}$ adenine sulfate) to the buffer solution during the pre-incubation. ${ }^{47}$

\section{Analysis of selenium species in red cell membranes}

To explore the selenium binding to the AE1 protein, red cell membranes isolated from the SA-treated red cells were electrophoresed on sodium dodecyl sulfate-polyacrylamide gels, and then the selenium contents of the protein bands were analyzed by the DAN method subsequent to acid digestion. Nearly half of the total selenium in the membranes was found in band 3, while the rest was in bands 1 and 2 that are assigned to spectrins (Fig. 2 a). The red cell membranes were fractionated into four fractions (N-CPD-, peripherals-, $\mathrm{C}-\mathrm{CPD}-$ and MSD-containing fractions) by enzymatic digestions and alkaline treatment, and their selenium contents were determined by the DAN method subsequent to acid digestion (Fig. 2 b). The selenium was detected in fractions (i), (iii) and (iv) which, respectively, contain the three domains of AE1: $42.7 \pm 1.2 \%$ in the N-CPD-containing fraction, $7.8 \pm 0.8 \%$ in the C-CPD-containing fraction and $21.0 \pm 1.7 \%$ in the MSD-containing fraction.

Because most selenium ( $>98 \%$ ) in the SA-treated red cells is bound to the Cys $\beta 93$ of $\mathrm{Hb}^{39}$, the $\mathrm{Hb} \beta$ chain was initially analyzed by MALDI TOF mass spectrometry. The $\mathrm{Hb} \beta$ chain from the SA-treated red cells gave a peak at $16.254 \times 10^{3} \mathrm{~m} / \mathrm{z}$ (Fig. $\left.2 \mathrm{c}-2\right)$, resulting in an increase in $m / z$ by $0.386 \times 10^{3}$ in comparison to that from the non-treated one (Fig. $2 \mathrm{c}-1$ ). Such an increase in the molecular mass of the $\mathrm{Hb} \beta$ chain corresponded to the selenenyl-glutathione (SeS-G) moiety, demonstrating the formation of Hb-Cys $\beta$ 93-SSeS-G 
species. Treatment of the red cell membranes with dithiothreitol, which reductively cleaves disulfide and trisulfide bonds, almost quantitatively eliminated the selenium bound to the membranes, thus indicating that the thiols of the membranes participated in the selenium binding. A Cys317-containing fragment of the N-CPD without the SA treatment was detected at $3.635 \times 10^{3} \mathrm{~m} / \mathrm{z}$ (Fig. $2 \mathrm{~d}-1$ ), which was identified by theoretical mass calculation using the protein prospector program and the molecular mass gain in $m / z$ by $0.125 \times 10^{3}$ after alkylation with NEM (Fig. 2 d-2). The membrane sample from the SA-treated red cells provided a peak at $4.021 \times 10^{3} \mathrm{~m} / \mathrm{z}$, resulting in an increase in $\mathrm{m} / \mathrm{z}$ by $0.380 \times 10^{3}$ in comparison to that from the non-treated ones (Fig. 2 d-3). The observed increase in the molecular mass of the Cys317-containing fragment corresponded to the SeS-G moiety, similar to that for the $\mathrm{Cys} \beta 93$ of $\mathrm{Hb}$.

\section{Reactivity of AE1 thiols with selenotrisulfide}

The reactivity of the AE1 thiols with selenotrisulfide was investigated using Pen-SSeS-Pen as a small-molecule probe (Fig. 3 a). The Pen-SSeS-Pen could be reactive with thiols of not only peripheral proteins but also integral ones, because of its membrane-penetrating character. After the reaction of unsealed red cell membranes with Pen-SSeS-Pen, the membranes were separated into the four fractions (N-CPD, peripherals, C-CPD and MSD), and their selenium contents were determined. The N-CPD-, the MSD- and the C-CPD-containing fractions respectively contained $48.3 \pm 3.5,12.4 \pm 1.5$ and $5.1 \pm 0.8 \%$ of selenium in the membranes (Fig. 3 b). In the comparison to the SA-treated membranes (Fig. 2 b), similar trends of the selenium binding were found for the N-CPD- and the C-CPD-containing fractions, but the binding rate to the MSD-containing fraction decreased. 
To examine the mode of the reaction between the AE1 thiols and Pen-SSeS-Pen, thiol contents of the membranes and the mixture before and after the reaction were determined by the DTNB method. The thiol content of the membranes after the reaction decreased to 60.8 $\pm 1.0 \%$, whereas the thiol content of the mixture was $98.8 \pm 2.0 \%$ of that from the added membranes. Thus, overall oxidation-reduction events did not entirely occur in the reaction of Pen-SSeS-Pen with the membrane, and thiols corresponding to the $40 \%$ decrease in the membrane thiols were generated outside the membranes by the reaction.

In MALDI TOF spectrometric analysis, a Cys317-containing fragment from the Pen-SSeS-Pen-treated membrane gave a peak at $3.863 \times 10^{3} \mathrm{~m} / \mathrm{z}$ (Fig. $3 \mathrm{c}-3$ ), resulting in an increase in $\mathrm{m} / \mathrm{z}$ by $0.226 \times 10^{3}$ in comparison to the non-treated one (Fig. $3 \mathrm{c}-1$ ). Such an increase in the molecular mass corresponded to that of the selenenyl-penicillamine (SeS-Pen) moiety, indicating that Pen-SSeS-Pen can be reacted with Cys317 through thiol exchange to form selenotrisulfide (N-CPD-Cys317-SH + Pen-SSeS-Pen $\rightarrow$ N-CPD-Cys317-SSeS-Pen +

Pen-SH). A SeS-Pen-adduct peak at $6.183 \times 10^{3} \mathrm{~m} / z$ (Fig. 3 e-1) was detected for a Cys843-containing fragment of the MSD (Fig. 3 e-1), whereas no similar adduct peak was for a Cys479-containing fragment of the MSD (Fig. 3 d-1 and d-3).

\section{Effects of thiol modification on the selenium binding to MSD}

The reaction manner between selenotrisulfide and the AE1 thiols was further examined using the membranes that were chemically modified with thiol-alkylating agents, NEM and IAA. Under the conditions used in this study, the NEM treatment alkylated $\approx 50 \%$ of the thiols of the N-CPD, but none of the MSD and the C-CPD. While the IAA treatment modified $\approx$ $80 \%$ of the thiols of the N-CPD, $\approx 30 \%$ of the MSD and $\approx 40 \%$ of the C-CPD (Fig. $4 \mathrm{a}-\mathrm{c}$ ). 
These thiol-modified membranes were incubated with Pen-SSeS-Pen, and their selenium contents of the MSD fraction were compared to that of the non-treated one. The selenium content of the MSD in the NEM-treated membranes decreased to less than half of that of the non-treated ones, even though its thiols were not modified at all. Likewise, for the IAA-treated membranes, the selenium from Pen-SSeS-Pen did not bind to the MSD, although $\approx 70 \%$ of the thiols of the MSD were in the free form (Fig. $4 \mathrm{~d}$ ), and the unsealed membranes could be reacted with the Pen-SSeS-Pen on both their cyto- and exoplasmic faces.

\section{Export of the membrane-bound selenium to the plasma}

To investigate the selenium transport manner in the red cell membranes, the resealed membranes from the SA-treated red cells were incubated in the plasma, and the selenium contents of the four membrane fractions were determined at the indicated time interval (Fig.

5). The selenium bound to the resealed membranes were gradually exported to the plasma and decreased to $\approx 40 \%$ of that initially bound at 60 min after incubation. The selenium content of the N-CPD- and the MSD-containing fractions [fractions (i) and (iv) in Fig. 5] markedly decreased, while those of the peripherals- and the C-CPD-containing fractions showed little change. Thus, the selenium bound to the N-CPD and the MSD of the AE1 in the resealed membranes was preferentially exported to the plasma.

\section{Discussion}

The selenium export from the red cells to the plasma was distinct from the anion exchange process of the AE1 from the following viewpoints; (a) a kinetically slower process (cf. anion 
exchange turnover rate of $5 \times 10^{4}$ anions $\mathrm{s}^{-1}{ }^{48}$ ), (2) no inhibition by treatment with a typical AE1 inhibitor DIDS, (c) complete export inhibition by $4{ }^{\circ} \mathrm{C}$ operation, and (d) export inhibition under an ATP depletion condition (Fig. 1). The selenium export from the SA-treated red cells involved an ATP-dependent mechanism. This export process did not occur in plain isotonic buffer solutions and required thiols in the outer medium. ${ }^{49}$ In addition, when an isotonic penicillamine solution instead of the plasma was used in the selenium export experiment, the selenium species exported was found in the chemical form of Pen-SSeS-Pen. ${ }^{49}$ Separately, we reported that the chemical modification of thiols of red cell membranes results in complete inhibition of the selenium export from the red cells to the plasma. $^{40}$ Biogenic thiols in the bloodstream, such as $\mathrm{Hb}$ and glutathione in red cells and albumin in the plasma, can participate in the metabolism and/or transport of selenium species inside the red cells and the subsequent transport to the peripherals. ${ }^{39,45,49}$ The thiols of spectrins can be interactive with glutathione to form disulfide bond, which associates to the flexible deformation of red cells in the peripheral capillaries. ${ }^{50}$ Thus, spectrin thiols could possibly interact with selenium metabolites, and the selenium binding to spectrins was actually observed (Fig. 2a). In our previous study using red cell inside-out vesicles, we demonstrated that selenium bound to $\mathrm{Hb}$ in the red cells is not transported to the N-CPD-deleted red cell membrane at all. ${ }^{39}$ The vast majority of selenium (> $98 \%$ of the total amount) in the SA-treated red cells is bound to $\mathrm{Hb}^{39}$ The selenium transport from $\mathrm{Hb}$ to the N-CPD of AE1 was thought to be the prerequisite event for the subsequent membrane transport of selenium to the plasma. Thus, the scaffold protein spectrins are unlikely to directly transport out selenium to the plasma. The selenium bound to spectrins probably comes from the interaction with low-mass selenium species, such as G-SSeS-G. The thiols 
of the integral protein AE1 were likely to play a role in the selenium transport across the red cell membrane. Taking these features together, the selenium export from the red cells to the plasma was thought to involve a function of the AE1 that is mediated by its thiols, not the already known the anion exchange function.

A large fraction of selenium in the membranes from the SA-treated red cells was bound to the N-CPD, the C-CPD and the MSD (Fig. $2 \mathrm{a}$ and b), which supported participation of the AE1 in the membrane transport of selenium. MALDI TOF mass spectrometric detection of Hb-Cys $\beta 93-S S e S-G$ and N-CPD-Cys317-SSeS-G in the SA-treated red cells (Fig. 2 c-2 and d-3 demonstrated that the membrane transport of selenium could proceed in the form of selenotrisulfide. Therefore, these mass spectrometric data also implicated that selenium from the Hb-Cys $\beta 93-\mathrm{SSeS}-\mathrm{G}$ is transported to the Cys 317 on the basis of the intrinsic interaction of $\mathrm{Hb}$ with the N-CPD (N-CPD-Cys317-SH + Hb-Cys $\beta$ 93-SSeS-G $\rightarrow$ N-CPD-Cys317-SSeS-G + Hb-Cys $\beta 93-\mathrm{SH})$. The selenium bound to the $\mathrm{Hb}$ seemed to be transported to the N-CPD of the AE1 in a manner similar to the NO bioactivity export from red cells $(\mathrm{Hb}-\mathrm{Cys} \beta 93-\mathrm{SNO}+\mathrm{N}-\mathrm{CPD}-\mathrm{Cys}-\mathrm{SH} \rightarrow \mathrm{Hb}-\mathrm{Cys} \beta 93-\mathrm{SH}+\mathrm{N}-\mathrm{CPD}-\mathrm{Cys}-\mathrm{SNO}){ }^{36}{ }^{33}$

On the basis of the mass spectrometric analysis of the SA-treated red cell membranes and $\mathrm{Hb}$, selenotrisulfide was thought to be the structural moiety to be transferred during the membrane transport of selenium. Thus, the reactivity of the AE1 thiols with selenotrisulfide was investigated using Pen-SSeS-Pen. Pen-SSeS-Pen itself is chemically stable under physiological conditions and is reactive with various thiols. Thiol exchange between selenotrisulfide and thiol is a reversible reaction and proceeds without changing the thiol content in the reaction mixture [R-SSeS-R + 2 R'-SH $\leftrightarrow($ R-SSeS-R' + R-SH + R'-SH) $\leftrightarrow$ R'-SSeS-R' + 2 R-SH]. Such a thiol exchange mechanism can provide a possible 
explanation for the reaction of Pen-SSeS-Pen with the unsealed red cell membranes, and the selenium from Pen-SSeS-Pen was bound to the membrane in the form of selenotrisulfide via thiols of the membranes. In fact, MALDI-TOF mass spectrometry independently confirmed that the selenotrisulfide adduct of the Cys317-containing fragment (N-CPD-Cys317-SSeS-Pen) was generated from the reaction of Pen-SSeS-Pen with the unsealed red cell membranes, as observed for the SA-treated membranes. A similar adduct of the Cys843-containing fragment demonstrated that selenotrisulfide could possibly be reacted with this thiol through thiol exchange. In aqueous media, thiol reagents can react with ionized thiol groups $\left(\mathrm{R}-\mathrm{S}^{-}\right)$about $5 \times 10^{9}$-fold faster than with un-ionized ones $(\mathrm{R}-\mathrm{SH}){ }^{51}$ A thiol on the membrane lipid-accessible surface will be less reactive, because its ionization is suppressed due to the low dielectric constant of the environment. ${ }^{52}$ Thus, thiols in the membrane lipid-accessible surface will be much less reactive with thiol reagents than those in the water-accessible surface. Actually, the thiols of the MSD in both the NEM- and the IAA-treated red cell membranes remained in part to be modified. Because the AE1 is reported to undergo palmitoylation through the thiol of the Cys843 of the MSD, ${ }^{53}$ and this thiol also allowed alkylating with NEM (Fig. 3 e-2), the thiol of the Cys843 could possibly provide a reaction site for selenotrisulfide. On the other hand, the other Cys residue of the MSD (Cys479) was unlikely to be reactive with selenotrisulfide.

The selenium from Pen-SSeS-Pen (Fig. 3 b) was less transferrable to the MSD in comparison to that from the Hb-Cys $\beta 93-\mathrm{SSe}-\mathrm{G}$ (Fig. 2 b). When NEM and IAA incompletely modified the thiols of the MSD, the proportion of selenium bound to the MSD was not entirely dependent on their thiol contents (Fig. 4 d). Thus, the selenium binding to the MSD was thought to be not due to the direct thiol exchange between $\mathrm{Hb}-\mathrm{Cys} \beta$ 93-SSe-G 
and the thiols of the MSD. In addition, when used the isotonic phosphate buffer containing penicillamine instead of the plasma in the selenium export experiment, the selenium species exported was found in the chemical form of selenotrisulfide. ${ }^{41}$ These results suggested a relay mechanism for the selenium transport from the N-CPD to the MSD in the AE1 protein. To verify such a relay mechanism of the AE1 in the membrane transport of selenium, the selenium export from the resealed membranes from the SA-treated red cells to the plasma was examined. The exported selenium to the plasma was dominantly attributed to that of N-CPD and MSD (Fig. 5), which suggested that thiols of N-CPD and MSD in AE1 serve as relay points in the membrane transport of selenium. On the other hand, the selenium bound to C-CPD and the peripherals did not appear to be concerned with the selenium export to the plasma. The selenium bound to the Cys317 of N-CPD seems to be intra- and/or intermolecularly relayed to the thiols of Cys843 of MSD and is subsequently exported to the plasma. The thiol of Cys479 on a lipid-accessible surface may not be involved as a relay site of selenium to be exported from the thiols of N-CPD to the plasma, because this thiol was much less reactive with selenotrisulfide and other thiol-reactive reagents than that of Cys843. Taking these features together, the AE1 thiol-mediated selenium transport across the membrane was thought to involve a relay mechanism of thiol exchange; Hb-Cys $\boldsymbol{\beta 9 3}-\mathbf{S S e S}-\mathbf{G}$ + N-CPD-Cys317-SH $\rightarrow$ Hb-Cys $\beta 93-S H+$ N-CPD-Cys317-SSeS-G + MSD-Cys843-SH

$\rightarrow$ N-CPD-Cys317-SH + MSD-Cys843-SSeS-G + HSA-Cys34-SH $\rightarrow$ MSD-Cys843-SH + HSA-Cys34-SSeS-G (Fig. 6).

\section{Conclusions}

In conclusion, the erythroid integral protein AE1 mediated the membrane transport of 
selenium from the red cells to the plasma in a thiol-dependent manner that is distinct from the already known anion exchange function. In this pathway, thiol-reactive substances bound to the $\mathrm{Hb}-\mathrm{Cys} \beta 93$ such as selenium can be transported by the relay mechanism to thiols of the $\mathrm{N}-\mathrm{CPD}$ of the AE1 on the basis of the intrinsic interaction between the two proteins and then subsequently exported to the plasma via the thiols of MSD. This membrane transport mechanism would function in the export processes of $\mathrm{NO}$ vasodilator activity and other substances bound to the $\mathrm{Hb}-\mathrm{Cys} \beta 93$ from red cells to the plasma and/or peripherals. The selenium export from the red cells to the plasma was also an energy-dependent process. 


\section{References}

1 M. P. Rayman, Lancet, 2000, 356, 233-241.

2 G. V. Kryukov, S. Castellano, S. V. Novoselov, A. V. Lobanov, O. Zehtab, R. Guigó and V. N.

Gladyshev, Science, 2003, 300, 1439-1443.

3 L. Flohe, W. A. Günzler and H. H. Schock, FEBS Lett., 1973, 32, 132-134.

4 Y. Saito and K. Takahashi, Eur. J. Biochem., 2002, 269, 5746-5751.

5 L. Schomburg, U. Schweizer, B. Holtmann, L. Flohó, M. Sendtner and J. Köhle, Biochem. J., 2003, 370, 397-402.

6 R. F. Burk, K. E. Hill, G. E. Olson, E. J. Weeber, A. K. Motley, V. P. Winfrey and L. M. Austin, J. Neurosci., 2007, 27, 6207-6211.

7 G. E. Olson, V. P. Winfrey, S. K. Nagdas, K. E. Hill and R. F. Burk, J. Biol. Chem., 2007, 282, 12290-12297.

8 R. F. Burk and K. E. Hill, Annu. Rev. Nutr., 2005, 25, 215-235.

9 X. Chen, G. Yang, J. Chen, X. Chen, Z. Wen and K. Ge, Biol. Trace Elem. Res., 1980, 2, 91-107.

10 L. Liang, S. Mo, P. Zhang, Y. Cai, S. Moua, G. Jiang and M. Wen, J. Chromatogr. A, 2006, 1118, $139-143$.

11 H. Li, Y. Luo, Z. Li, L. Yang and Q. Wang, Anal. Chem., 2012, 84, 2974-2981.

12 P. V. Dael, L. Davidsson, R. Muñoz-Box, L. B. Fay and D. Barclay, Br. J. Nutr., 2001, 85, $157-163$

13 J. D. Carver, Am. J. Clin. Nutr., 2003, 77, 1550S-1554S.

14 T. K. Suzuki, Y. Shiobara, M. Itoh and M. Ohmichi, Analyst, 1998, 123, 63-67.

15 A. Mas, J. Jiang and B. Sarkar, Biol. Trace Elem. Res., 1988, 15, 97-110.

16 K. T. Suzuki and M. Itoh, J. Chromatogr. B, 1997, 692, 15-22.

17 Y. Shiobara and K. T. Suzuki, J. Chromatogr. B, 1998, 710, 49-56.

18 G. Fairbanks, T. L. Steck and D. F. H. Wallach, Biochemistry, 1971, 10, 2606-2617.

19 R. R. Kopito and H. F. Lodish, Nature, 1985, 316, 234-238.

20 M. J. A. Tanner, P. G. Martin and S. High, Biochem. J., 1988, 256, 703-712.

21 S. E. Lux, K. M. John, R. R. Kopito and H. F. Lodish, Proc. Natl. Acad. Sci. U.S.A., 1989, 86, 9089-9093.

22 L. J. Bruce, R. Beckmann, M. L. Ribeiro, L. L. Peters, J. A. Chasis, J. Delaunay, N. Mohandas, D. J.

Anstee and M. J. A. Tanner, Blood, 2003, 101, 4180-4188.

23 D. Sterling, R. A. F. Reithmeier and J. R. Casey, J. Biol. Chem., 2001, 276, 47886-47894.

24 S. L. Alper, Exp Physiol., 2005, 91, 153-161. 
25 P. S. Low, Biochim. Biophys. Acta, 1986, 864, 145-167.

26 J. A. Walder, R. Chatterjee, T. L. Steck, P. S. Low, G. F. Mussofg, E. T. Kaiser, P. H. Rogers and A.

Amone, J. Biol. Chem., 1984, 259, 10238-10246.

27 S. H. Chang and P. S. Low, J. Biol. Chem., 2003, 278, 6879-6884.

28 V. Bennett and P. J. Stenbuck, J. Biol. Chem., 1980, 255, 6424-6432.

29 A. C. Rybicki, R. S. Schwartz, E. J. Hustedt and C. E. Cobb, Blood, 1996, 88, 2745-2753.

30 R. G. Langdon and V. P. Holman, Biochim. Biophys. Acta, 1988, 945, 23-32.

31 S. L. Alper, Exp. Physiol., 2006, 91, 153-161.

32 J. R. Casey, Y. Ding and R. R. Kopito, J. Biol. Chem., 1995, 270, 8521-8527.

33 S. Grinstein, S. Ship and A. Rothstein, Biochim. Biophys. Acta, 1978, 507, $294-304$.

34 S. Lepke, A. Becker and H. Passow, Biochim. Biophys. Acta, 1992, 1106, 13-16.

35 J. M. Sayare and M. Fikiet, J. Biol. Chem., 1981, 256, 13152-13158.

36 J. R. Pawloski, D. R. Hess and J. S. Stamler, Nature, 2001, 409, 622-626.

37 T. J. McMahon, R. E. Moon, B. P. Luschinger, M. S. Carraway, A. E. Stone, B. W. Stolp, A. J. Gow,

J. R. Pawloski, P. Watke, D. J. Singel, C. A. Piantadosi and J. S. Stamler, Nat. Med., 2002, 8, $711-717$.

38 K. N. Houk, B. N. Hietbrink, M. D. Bartberger, P. R. McCarren, B. Y. Choi, R. D. Voyksner, J. S.

Stamler and E. J. Toone, J. Am. Chem. Soc., 2003, 125, 6972-6976.

39 M. Haratake, K. Fujimoto, R. Hirakawa, M. Ono and M. Nakayama, J. Biol. Inorg. Chem., 2008, 13, 471-479.

40 M. Haratake, M. Hongoh, M. Ono, and M. Nakayama, Inorg. Chem., 2009, 48, 7805-7811.

41 J. Watkinson, Anal. Chem., 1966, 38, 92-97.

42 T. L. Steck and J. A. Kant, Methods Enzymol., 1974, 31, 173-180.

43 Y. Abe, T. Hamasaki, S. Turusaki, S. Takazakia, X. Jina, D. Kanga and N. Hamasaki, Protein Pept. Lett., 2006, 13, 761-767.

44 M. Haratake, M. Ono and M. Nakayama, J. Health Sci., 2004, 50, 366-371.

45 M. Haratake, K. Fujimoto, M. Ono and M. Nakayama, Biochim. Biophys. Acta, 2005, 1723, $215-220$.

46 J. J. Falke and S. I. Chan, Biochemistry, 1986, 25, 7895-7898.

47 C. J. Feo and P. F. Leblond, Blood, 1974, 44, 639-647.

48 J. Brahm, J. Gen. Physiol., 1977, 77, 283-306.

49 M. Haratake, M. Hongoh, M. Miyauchi, R. Hirakawa, M. Ono and M. Nakayama, Inorg. Chem., $2008,47,6273-6280$.

50 C. P. Johnson, H.-Y. Tang, C. Carag, D. W. Speicher and D. E. Discher, Science, 2007, 317, $663-666$. 
51 D. D. Roberts, S. D. Lewis, D. P. Ballou, S. T. Olson and J. A. Shafer, Biochemistry, 1986, 25, $5595-5601$.

52 A. Karlin and M. H. Akabas, Methods Enzymol., 1998, 293, 123-145.

53 K. Okubo, N. Hamasaki, K. Hara and M. Kageura, J. Biol. Chem., 1991, 266, 16420-16424. 

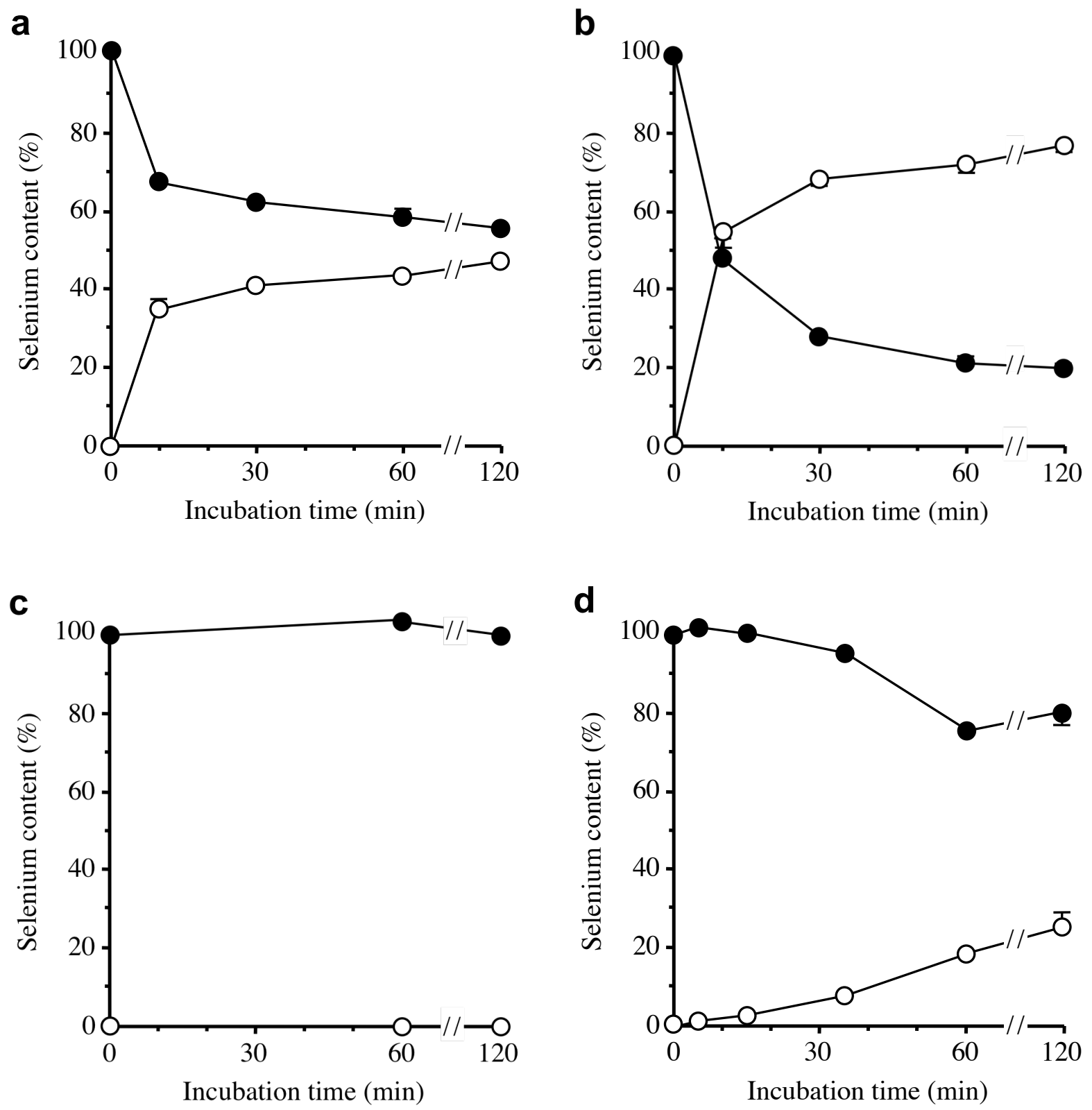

Fig. 1. Selenium export from red cells to the plasma. Red cells were treated with $8 \mu \mathrm{M}$ SA and then incubated in the plasma under various conditions: (a) incubated in the plasma at 37 ${ }^{\circ} \mathrm{C}$ (control), (b) treated with $50 \mu \mathrm{M}$ DIDS at $37^{\circ} \mathrm{C}$ for $10 \mathrm{~min} 37^{\circ} \mathrm{C}$ prior to combine with the plasma, (c) incubation in the plasma at $4{ }^{\circ} \mathrm{C}$, (d) incubated in the isotonic phosphate buffer (pH 7.4) for $2 \mathrm{~h}$ prior to combine with the plasma at $37^{\circ} \mathrm{C}$. ATP concentrations in red cells

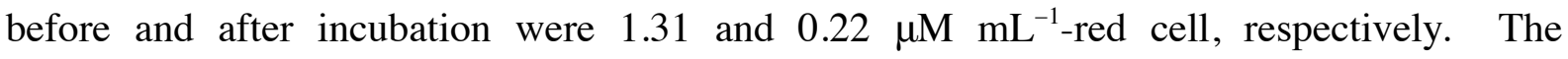
selenium amounts in the red cells at time 0 were defined as $100 \%$. Solid circle, selenium content in red cells; open circle, selenium content in the plasma. 
a

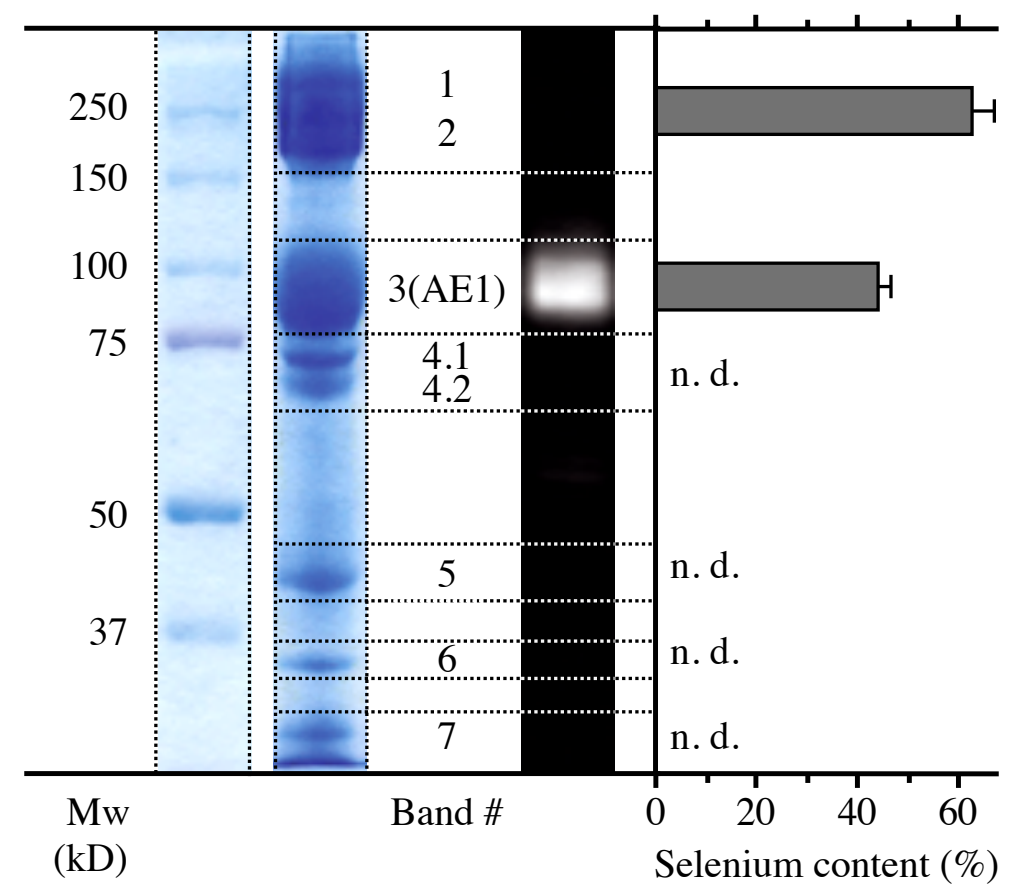

b
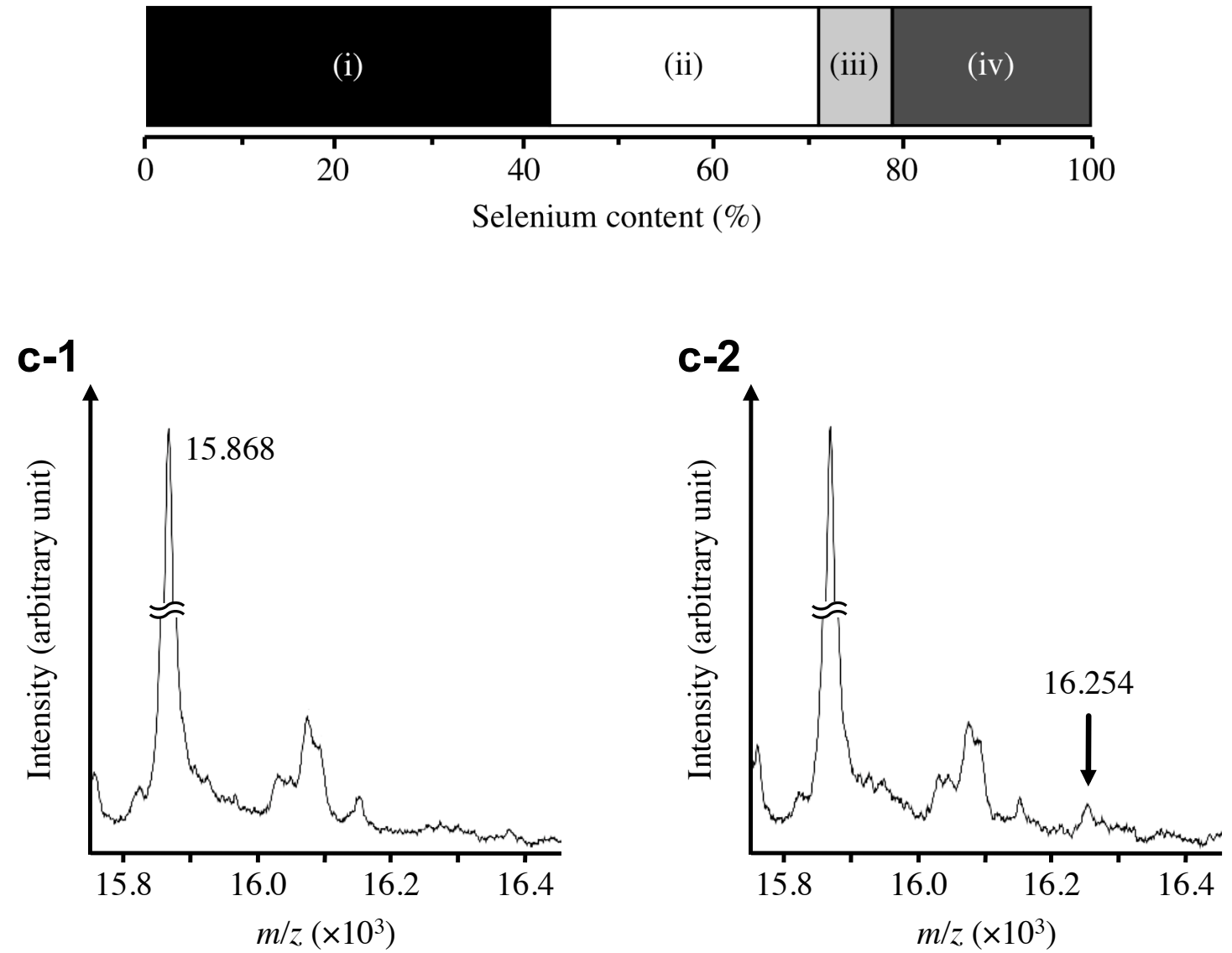

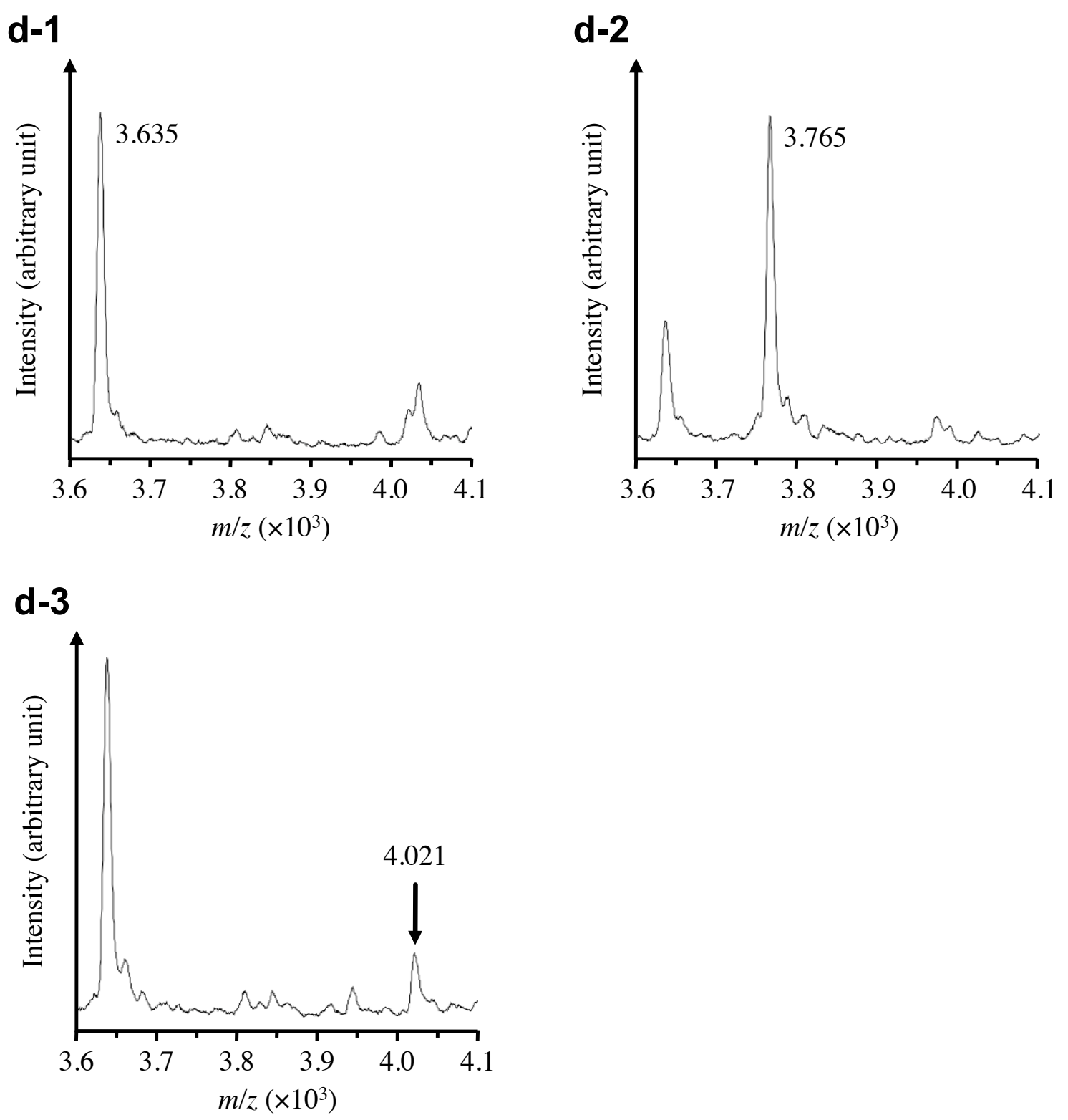

Fig. 2. Analysis of red cell membranes after treatment of SA. (a) SDS-PAGE of the membranes and its western blotting using anti-AE1 antibody and measurements of selenium contents of the protein bands. n. d., not detected. (b) Selenium distribution in the membranes: fraction (i), \% released from the $\alpha$-Chy digestion; (ii), $\%$ released from the $\mathrm{NaOH}$ extraction, (iii), \% released from the Try digestion; (iv), \% remaining in the membrane after Try digestion. Red cells were treated with $8 \mu \mathrm{M}$ SA and osmotically hemolyzed. After thoroughly washing, the obtained red cell membranes were sequentially treated with 0.2 $\mathrm{mg} \mathrm{mL} \mathrm{m}^{-1} \alpha$-Chy for $10 \mathrm{~min}, 0.1 \mathrm{M} \mathrm{NaOH}$ for $30 \mathrm{~min}$ on ice and $25 \mu \mathrm{g} \mathrm{mL} \mathrm{m}^{-1}$ Try for $1 \mathrm{~h}$ at $37^{\circ} \mathrm{C}$. The selenium content of the red cell membranes before the treatment of $\alpha$-Chy was 
$0.097 \pm 0.006 \mathrm{ng} \mathrm{mg}^{-1}$-protein and defined as $100 \%$. (c-1) and (c-2) MALDI TOF mass spectra of $\mathrm{Hb} \beta$ chain: (c-1) treated without SA (calcd molecular mass $\left.15.851 \times 10^{3}\right),(\mathrm{c}-2)$ treated with $8 \mu \mathrm{M}$ SA. (d-1)-(d-3) MALDI-TOF MS spectra of Cys317-containing fragment of N-CPD (Asp316-Tyr347, calcd molecular mass $\left.3.637 \times 10^{3}\right):(\mathrm{d}-1)$, treated without SA; (d-2) treated with $1 \mathrm{mM}$ NEM; (d-3), treated with $8 \mu \mathrm{M}$ SA. Unsealed membranes from red cells treated without and with $8 \mu \mathrm{M} \mathrm{SA}$ were digested with $20 \mu \mathrm{gL}^{-1}$ $\alpha$-Chy in $5 \mathrm{P} 8$ at $37^{\circ} \mathrm{C}$ for $10 \mathrm{~min}$. After centrifugation at $20,000 \mathrm{~g}$, supernatant was used for the analysis. 
a<smiles>CC(C)(S[Se]SSC(C)(C)[C@H](N)C(=O)O)[C@@H](N)C(=O)O</smiles>

b
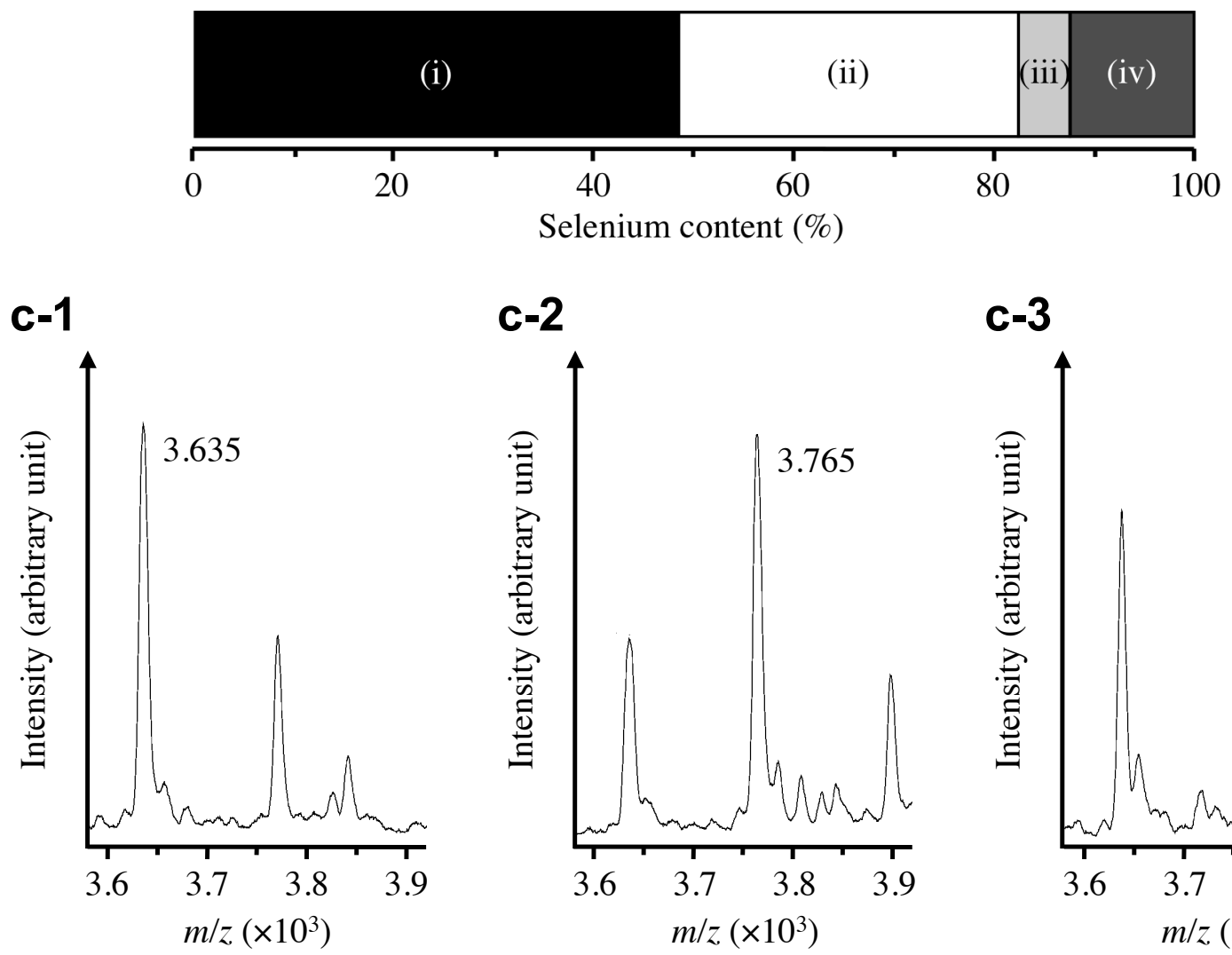

C-2

C-3
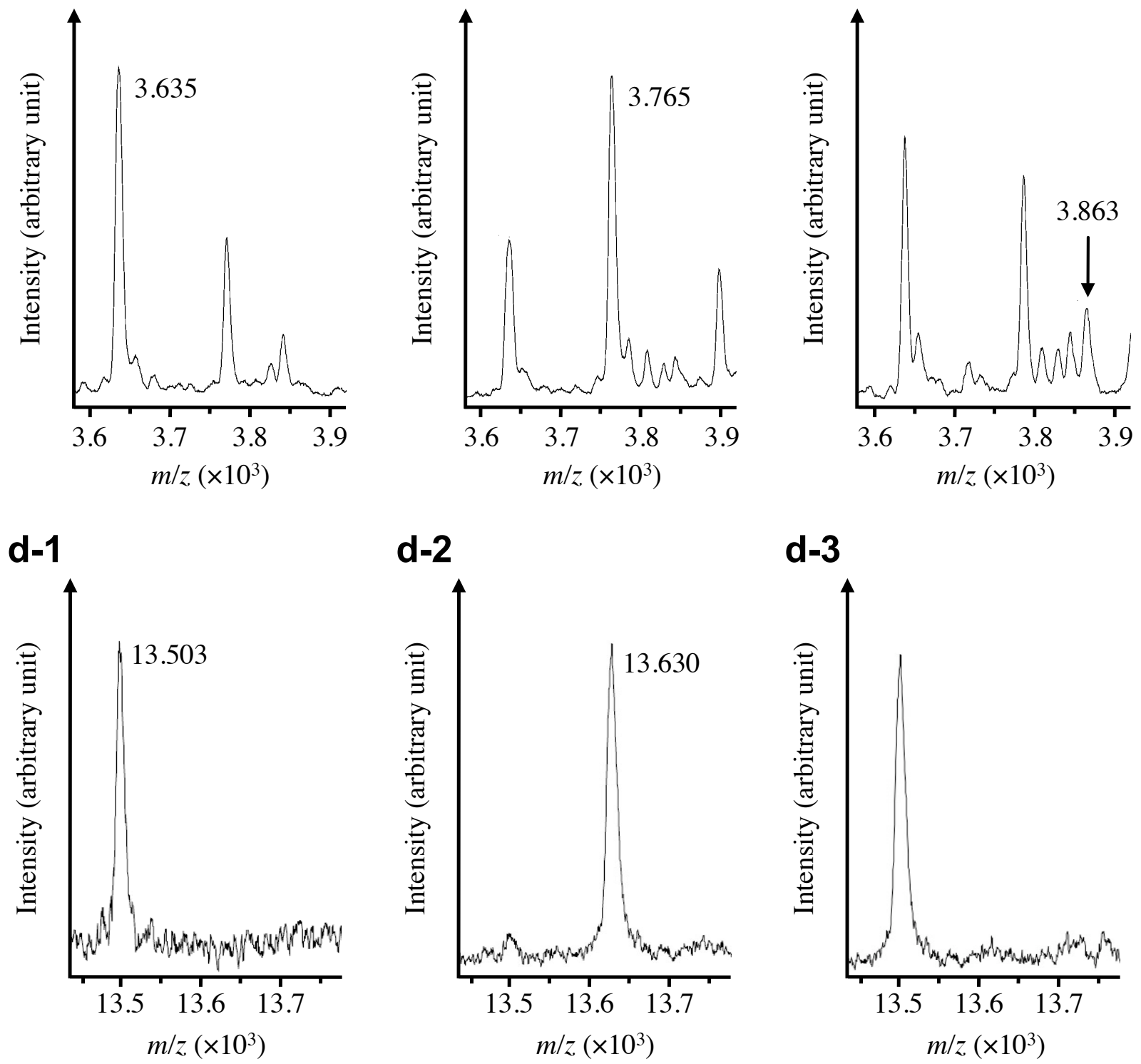

d-2

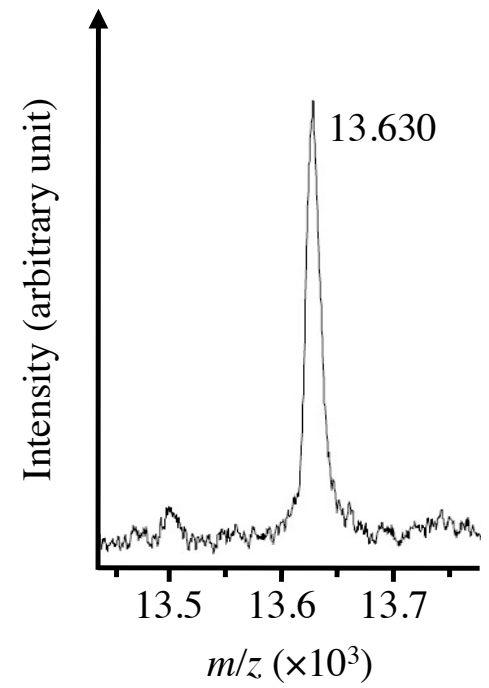

d-3

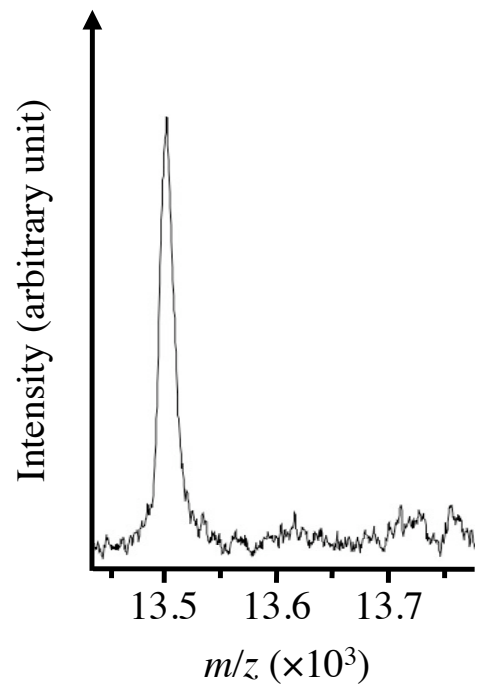



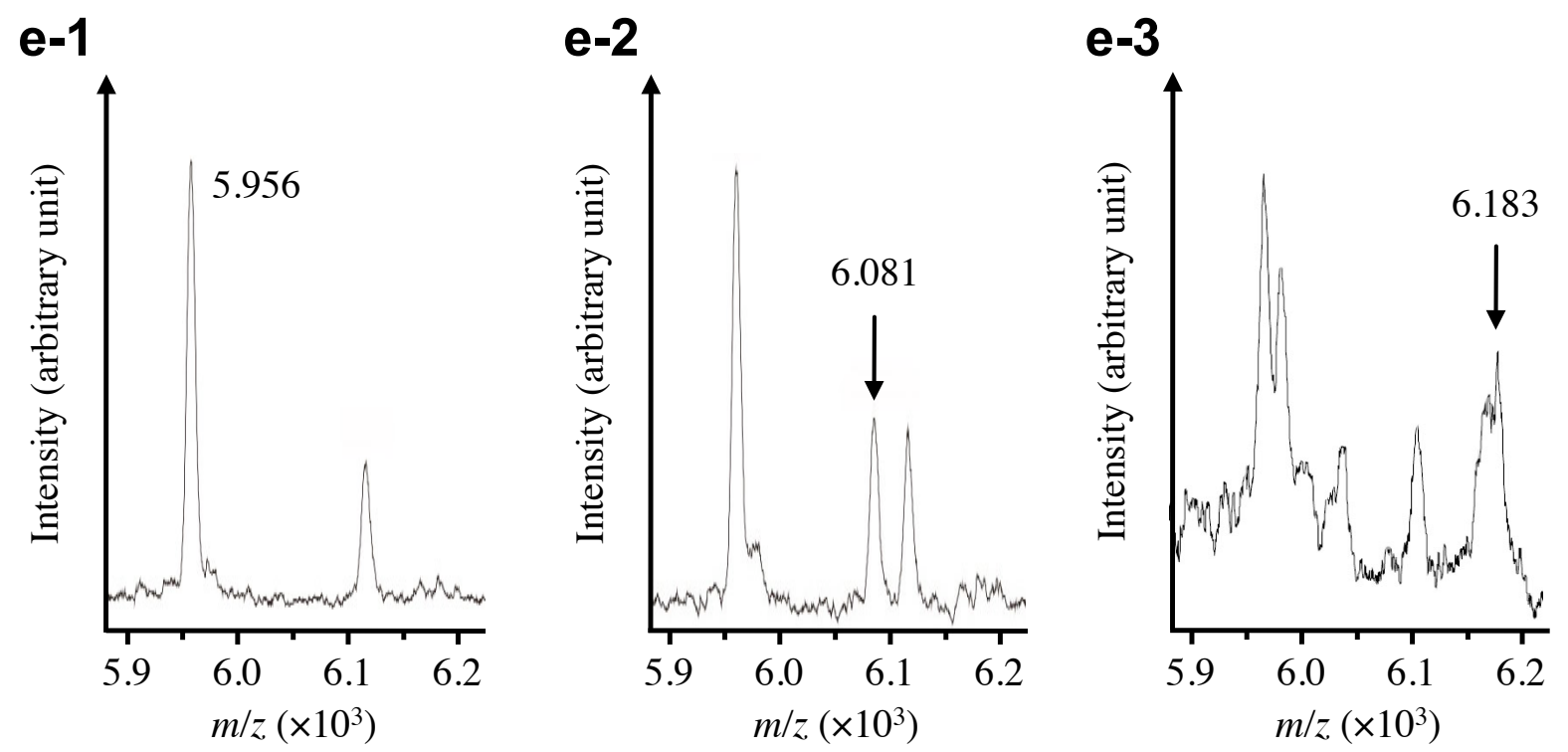

Fig. 3. Analysis of red cell membranes after treatment of Pen-SSeS-Pen. (a) Chemical structure of Pen-SSeS-Pen, (b) Selenium distribution in red cell membranes: fraction (i), \% released from the $\alpha$-Chy digestion; (ii), $\%$ released from the $\mathrm{NaOH}$ extraction; (iii), $\%$ released from the Try digestion; (iv), \% remaining in the membrane after the Try digestion. Unsealed red cell membranes were treated with $1 \mathrm{mM}$ Pen-SSeS-Pen for $10 \mathrm{~min}$ in the isotonic phosphate buffer ( $\mathrm{pH}$ 7.4). After thoroughly washing, the resulting membranes were sequentially treated with $0.2 \mathrm{mg} \mathrm{mL}^{-1} \alpha$-Chy for $10 \mathrm{~min}, 0.1 \mathrm{M} \mathrm{NaOH}$ for $30 \mathrm{~min}$ on ice and $25 \mu \mathrm{g} \mathrm{mL} \mathrm{L}^{-1}$ Try for $1 \mathrm{~h}$ at $37^{\circ} \mathrm{C}$. The selenium content of the red cell membranes after the treatment of Pen-SSeS-Pen was $0.78 \pm 0.03 \mathrm{ng} \mathrm{mg}^{-1}$-protein and defined as $100 \%$. (c-1)-(c-3) MALDI-TOF mass spectra of Cys317-containing fragments (Asp316-Tyr347, calcd molecular mass $\left.3.637 \times 10^{3}\right)$. (d-1)-(d-3) MALDI-TOF mass spectra of Cys479-containing fragments (Asn433-Lys551, calcd molecular mass $13.504 \times 10^{3}$ ). (e-1)-(e-3) MALDI-TOF mass spectra of Cys843-containing fragments (Val828-Arg879, calcd molecular mass $\left.5.956 \times 10^{3}\right) . \quad(\mathrm{c}-1),(\mathrm{d}-1)$ and $(\mathrm{e}-1)$, without treatment; $(\mathrm{c}-2),(\mathrm{d}-2)$ and (e-2), treated with $1 \mathrm{mM}$ NEM; (c-3), (d-3) and (e-3), treated with $0.1 \mathrm{mM}$ Pen-SSeS-Pen. Unsealed membranes were treated with $0.1 \mathrm{M} \mathrm{NaOH}$ and then allowed to react with $0.1 \mathrm{mM}$ Pen-SSeS-Pen. Cys317-containing fragment of the $\mathrm{N}-\mathrm{CPD}$ was collected by $20 \mu \mathrm{g} \mathrm{mL}$ $\alpha$-Chy digestion in $5 \mathrm{P} 8$ at $37{ }^{\circ} \mathrm{C}$ for $10 \mathrm{~min}$. After centrifugation at $20,000 \mathrm{~g}$, supernatant was used for the analysis. 

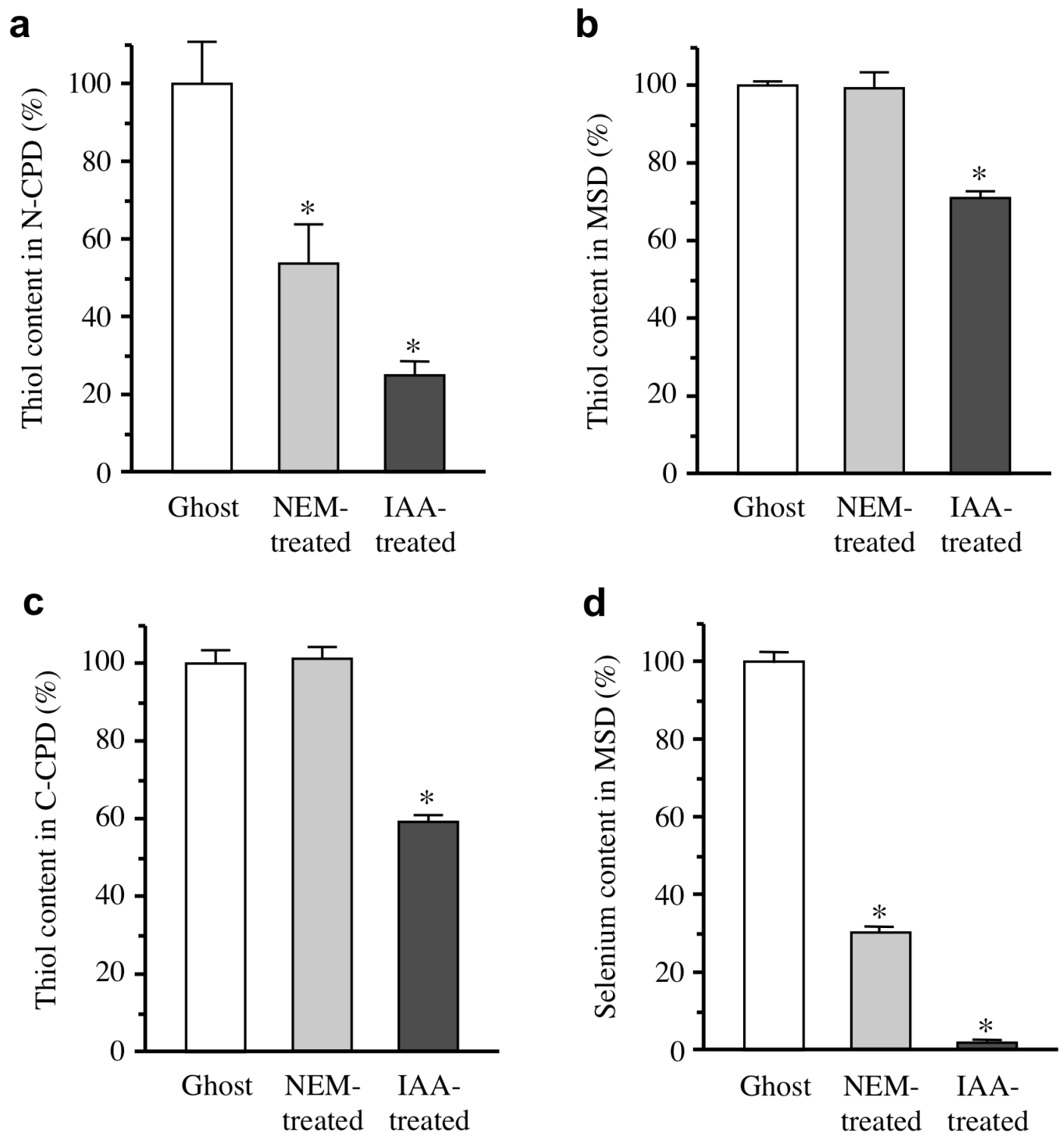

Fig. 4. Thiol and selenium contents of red cell membranes. (a)-(c) thiol contents of the N-CPD, MSD and C-CPD. (d) selenium content of the MSD after treatment with Pen-SSeS-Pen. Unsealed membranes were treated with $1 \mathrm{mM}$ NEM and $1 \mathrm{mM}$ IAA at $37{ }^{\circ} \mathrm{C}$ for $10 \mathrm{~min}$, and then with $0.1 \mathrm{mM}$ Pen-SSeS-Pen in 5P8. $* P<0.05$, significantly different from the ghost sample by a two-way analysis of variance. 


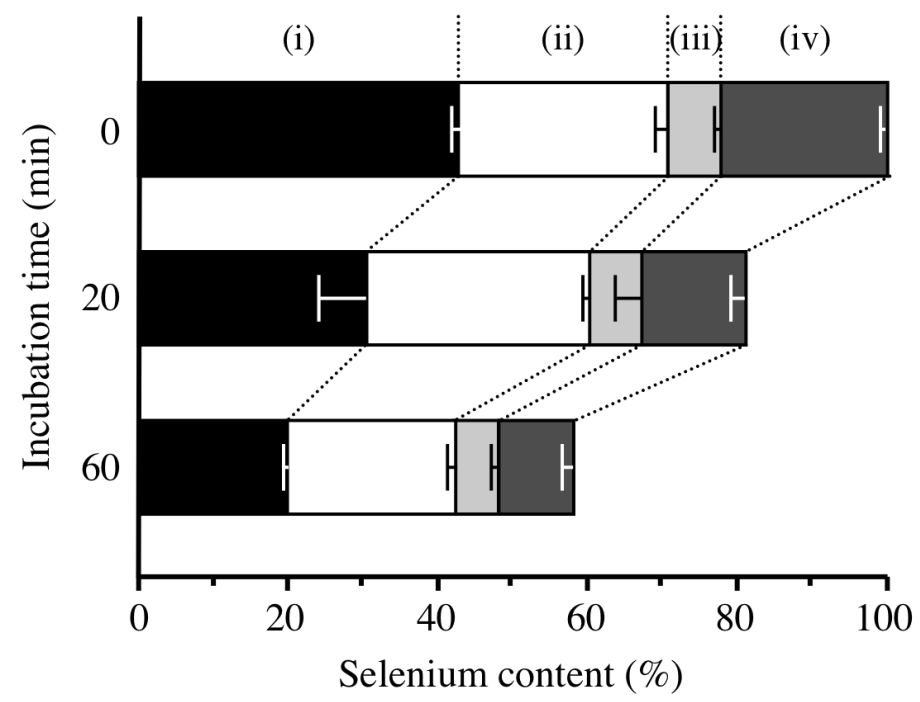

Fig. 5. Selenium export from resealed membranes to the plasma. Fraction (i), from the $\alpha$-Chy digestion: (ii), from the $\mathrm{NaOH}$ extraction, (iii), from the Try digestion: (iv), remaining in the membrane after the Try digestion. Resealed membranes from red cells treated with 8 $\mu \mathrm{M}$ SA were incubated in the plasma. The membranes were fractionated according to the procedure described in Methods section, and the selenium content in the each fraction was determined by the DAN method subsequent to acid-digestion. The selenium content of the red cell membranes before mixing with the plasma (at incubation time 0) was the same as that in Fig. 2 and defined as $100 \%$. 


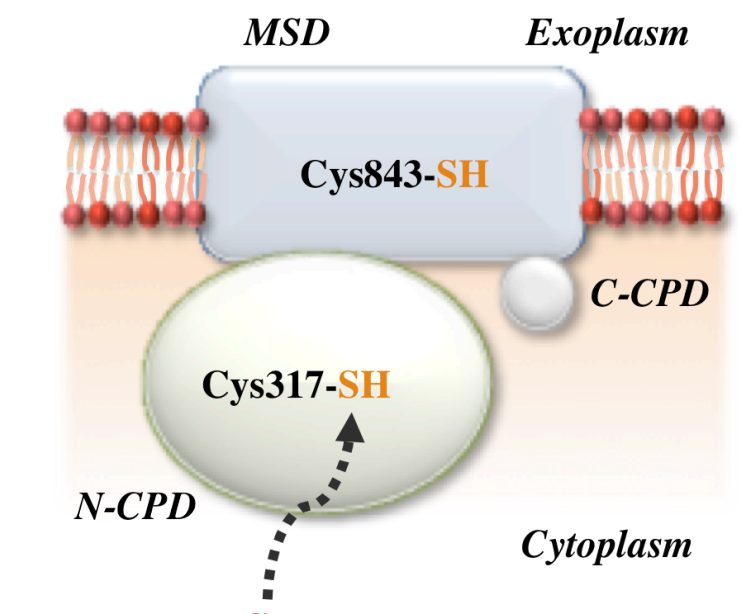

Hb-Cys $\beta$ 93-SSeSG
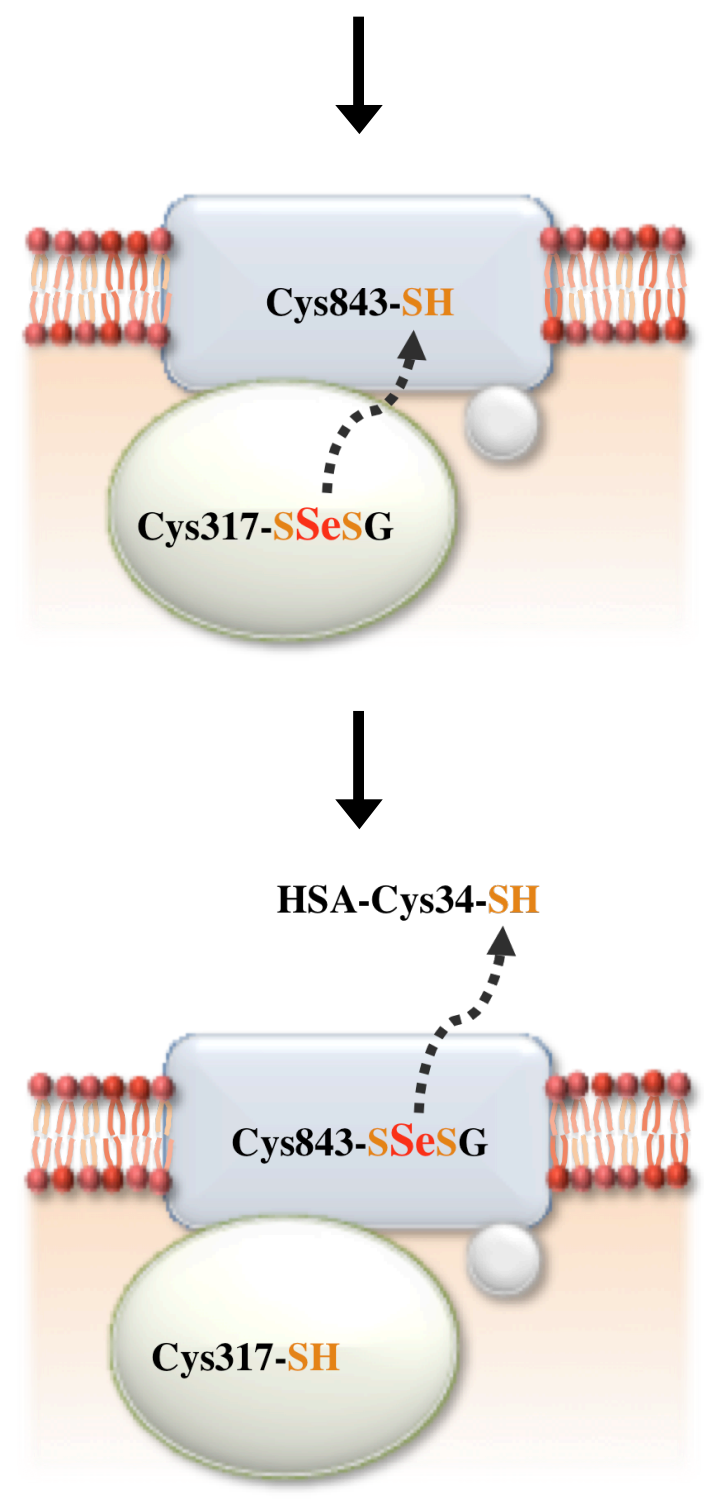

Fig. 6. A proposed mechanism of AE1 thiol-mediated membrane transport of selenium from red cells to the plasma. 


\section{Graphical abstract for the contents entry page}

We demonstrate that the erythroid anion exchanger 1 membrane protein (AE1) mediates the membrane transport of selenium, an essential antioxidant micronutrient, from red cells to the plasma in a thiol-mediated and energy-dependent manner that is distinct from the already known anion exchange function. In this pathway, selenium bound to the cysteine 93 of the hemoglobin $\beta$ chain (Hb-Cys $\beta 93$ ) is transported by a relay mechanism to the Cys 317 of the amino-terminal cytoplasmic domain of the AE1 on the basis of the intrinsic interaction between the two proteins and is subsequently exported to the plasma via the Cys843 of the membrane-spanning domain.

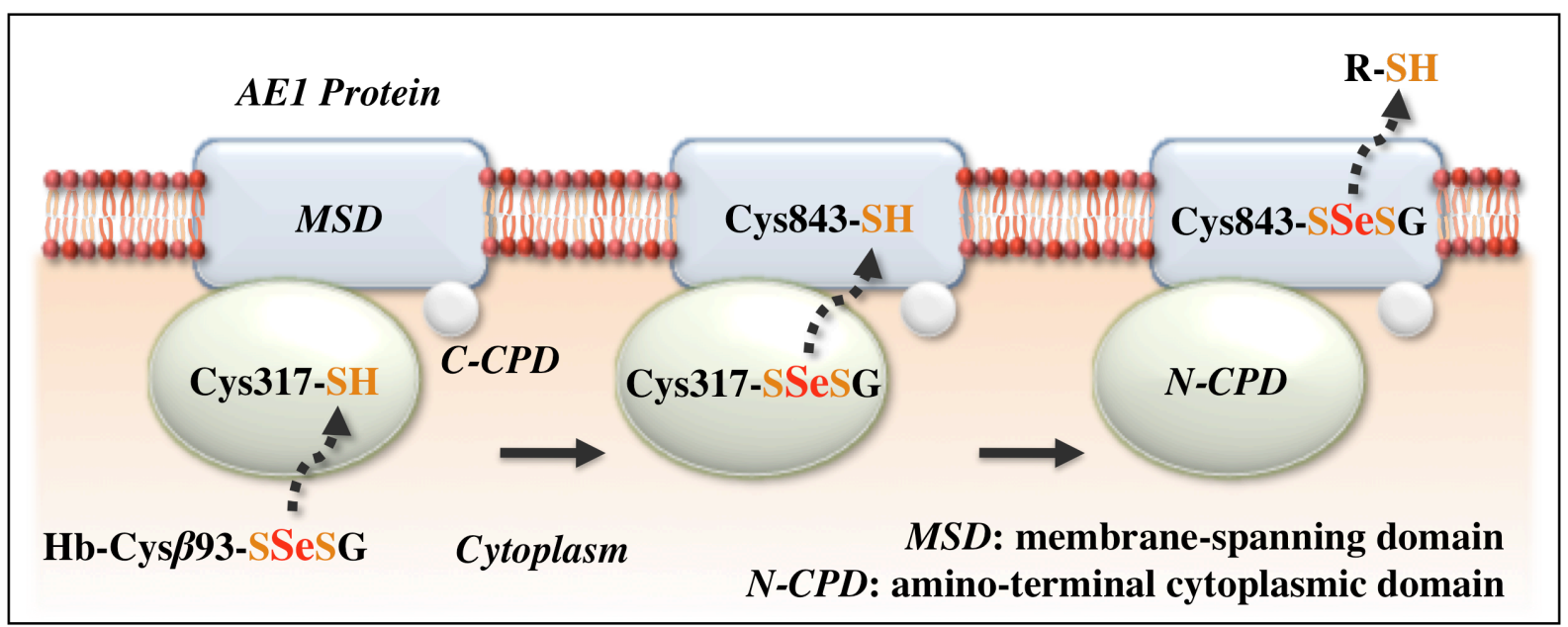

